\title{
MANF wt Allele
}

National Cancer Institute

\section{Source}

National Cancer Institute. MANF wt Allele. NCI Thesaurus. Code C54330.

Human MANF wild-type allele is located in the vicinity of 3p21.1 and is approximately $4 \mathrm{~kb}$ in length. This allele, which encodes mesencephalic astrocyte-derived neurotrophic factor protein, plays a role in both the modulation of GABA neurotransmission and the mediation of dopaminergic neuron survival. 